\title{
The Political Economy of Knowledge: Neglecting Politcal Economy in the Age of Fast Capitalism (As Before)
}

\author{
Robert Babe
}

In some ways postmodernist/poststructuralist thought is the ontology best supporting and depicting today's fast capitalism. Fast capitalism depends, after all, on the volume, speed, and territorial expanse of digitized communication networks, on reduced time for product cycles, on accelerating speeds of style and model changes, and perhaps most importantly on imagery embedding mythic meanings onto the banality of mass produced consumer items. Postmodernist/poststructuralist thought, likewise, addresses and presumes the fluidity, speed, exponential growth in, and easy transformation of symbolic structures in a digital age. [1]

Some maintain that postmodernist/poststructuralist thought, which began entering the mainstream of many American disciplines in the early 1980s, constitutes a huge break from the modernist and Enlightenment traditions (Webster 1995:163-75). In a number of ways this is true. The Enlightenment presumed, for example, that material reality exists independent of human thought, and that humans can learn about this reality by applying the (Baconian) scientific method of induction and deduction. For many postmodernists, by contrast, human culture is all-encompassing; we cannot stand outside culture.

However, I argue here, this cavernous dichotomy in ontology notwithstanding, since fast capitalism is still capitalism one can expect also to find deep-seated continuities between postmodernist thinking, especially as it becomes increasingly mainstream, and what went before. For as political philosopher C.B. Macpherson insisted (1978), mainstream discourses normally support or "justify" the prevailing political-economic order (pp. 11-12). Indeed, for Macpherson, such is their primary purpose.

Although the innovators of postmodernist discourses may very well have understood their project as constituting a radical break with the past, [2] and although contemporary critical postmodernists undoubtedly intend their work to challenge existing power structures, norms and received wisdoms, postmodernist thought can also, I will argue, be turned rather easily into a paradigm propping up established power, war, gross inequality and other forms of injustice, and indeed this is exactly what we should expect as it continues to enter mainstream discourses. Such is the dialectic of postmodernist thought.

I begin this paper by focusing on mainstream American media/communication/cultural studies scholarship as they evolved over the last 100 years to demonstrate the veracity of Macpherson's insight regarding dominant discourses sustaining established power. In so broad a survey I can, of course, touch down but briefly on key phases, but the upside is that clear patterns, indeed constancies, emerge. The period certainly witnessed dramatic changes in the predominant means of mediated communication-from local to regional and then to national press systems, the rise of cinema and broadcasting, and more recently the inauguration of computer communications, digitization, and the internet. Moreover, modes of transmission significantly expanded in capacity and in distance capability, with digital communication satellites being perhaps the apotheosis of that trend. For these reasons alone one could expect major revolutions in mainstream media/cultural studies scholarship.

But, to repeat, the fast capitalism of today is still capitalism, and if mainstream scholarship in the social sciences and humanities indeed tends to support prevailing structures of political-economic power, then deep- 
seated constancies over time should be evident in that scholarship_-despite fundamental changes in the modes of communication. I argue here, then, that as the predominant media of communication evolved from print, to film/broadcasting, to today's globalizing, digitized electronic communication, so too did mainstream scholarship in cultural and media studies, but in ways that consistently ignored disparities in communicatory power. At each stage, moreover, as I will point out, mainstream paradigms were belied by both real world events and practices, and by marginalized scholarship, making all the more convincing the political economy of knowledge thesis developed here.

The continuous neglect of political-economic aspects of information, media, communication, and culture is evident despite the fact (or more accurately, one suspects, due to the fact) that communication and culture have long been central to American wealth generation, governance, and foreign policy. Before documenting the argument, then, it is worthwhile speculating on reasons for this continuous inattention. To focus, for example, on asymmetries internationally in communicatory and cultural power would be to put into question, at least implicitly, the legitimacy or justness of those asymmetries, whereas to ignore them, obscure them, or to deem them insignificant makes seem more apt "free trade" in cultural "commodities" — a mainstay certainly of the official, "liberal," American paradigm. Similarly, to draw attention to domestic media ownership concentrations and to the role of advertising in "filtering" news and other content would be to raise grave doubts about the state of American democracy.

Today, the age of fast capitalism, the political economic stakes of influencing or controlling communication and culture grow exponentially. By the same token, the neglect of political economy in much of American media scholarship becomes all the more severe. It is in this context that an appraisal of postmodernist/poststructuralist scholarship needs to be undertaken, for by extrapolating past experience one can foresee a pronounced tendency for postmodernist thought, as it becomes ever-more mainstream, to likewise aid and abet domination by the politicalcorporate elite.

\section{The Chicago School in the Age of Print}

Standard histories of American communication/media studies begin by referencing the "Chicago School" of John Dewey, Robert Park and Charles Cooley (Czitrom 1982; Delia 1987; Hardt 1992; Rogers 1994 Carey 1996). For some intellectual historians, the Chicago theorists were foundational; for others, they were but precursors, or even merely "forefathers of the forefathers" (Schramm 1997:107). But virtually unanimously, the Chicago theorists are seminal.

In the early decades of the twentieth century, Dewey, Park, and Cooley inquired broadly from humanist perspectives into the role of media in American society. They viewed society as an organism, whose citizens are bound together through networks of transportation (likened to blood vessels) and communication (likened to nerves). They were progressivist theorists speculating on how technological change, particularly emerging media of communication, could and would enlighten citizens, foster community, and increase democracy. According to Dewey (1927), "the Great Society created by steam and electricity may be a society, but it is no community ... Communication alone can create a great community" (pp. 98, 141).

Indeed, Dewey seemed to hold to a doctrine of inevitable human betterment through technological change. Technologies, he opined, are instruments to solve problems, and as the problems change, so do the instruments. Through this doctrine of instrumentalism, he gave short shrift to other possibilities-war, domination and subordination through technological means, ecosystem collapse. The chief failing of the Chicago School, according to Czitrom (1982), was its "refusal to address the reality of social and economic conflict in the present" (p. 112). Tellingly, Dewey's plans for Thought News_a newspaper that "shall not go beyond the fact; which shall report thought rather than dress it up in the garments of the past," and that would use philosophic ideas as "tools in interpreting the movement of thought; which shall treat questions of science, letters, state, school and church as parts of one moving life of man" (Williams 1998:30)—never came to fruition.

Without Macpherson's insights, the naïve technological optimism of the Chicago theorists would be difficult to comprehend, given the uses to which media and other technologies were then being put. In 1917, for example, acting on the advice of Walter Lippmann, the Wilson Administration created the Committee on Public Information (CPI) as the government's propaganda arm for the Great War. CPI produced hundreds of ads promoting the war effort and pressured newspapers into giving it free advertising space. It distributed thousands of official news releases and war-related public interest stories. It even published its own newspaper (Ewan 1996:111-113). Meanwhile, the 
commercial press was "continually silenced by orders and prosecutions;" war critics were arrested, "often without warrants, hustled off to jail, held incommunicado without bail ...” (Beard and Beard 1930).

The war years, however, were not exceptional. They were, rather, fulfilling a nascent "control revolution" (Beniger 1986) that began prior to the turn of the century whereby image-based advertising of addictive and nonaddictive branded products presented "a nether realm between truth and falsehood ... The world of advertisements," according to Jackson Lears (1983), "gradually acquired an Alice-in-Wonderland quality" (p.21)—harbinger of postmodernist simulacra.

Writing contemporaneously with the Chicago School was Dewey's former student and arch nemesis, journalist Walter Lippmann. In his influential 1922 tome, Public Opinion, Lippmann argued that most of us, most of the time, live in a "pseudoenvironment," defined as the "way in which the world is imagined ... a hybrid compounded of 'human nature' and 'conditions"” (Lippmann 1965:17). On the one hand, Lippmann (1965) proposed, people inadvertently construct pseudoenvironments by unconsciously imposing stereotypes and preconceptions onto the reality around them; on the other, pseudoenvironments are purposefully fabricated for popular consumption by media practitioners skilled in manipulating symbols (p. 133). Lippmann foreshadowed such postmodernist constructs as simulacra and hyperreality.

Moreover, he was a precursor to the "crisis of democracy" position, as forwarded decades later by Zbigniew Brzezinski (1970) and the Trilateral Commission (Crozier, Huntington and Watanuki 1975) [3] and arguably as responded to by neoconservative governments through trade agreements (Barlow and Clark 1997) and antiterrorism legislation (Roberts 2005:F1-F5). [4] For Lippmann, democracy had turned a corner (he called it "a new image of democracy"), as experts now garnered popular consent for their policies by skillfully manipulating pseudoenvironments while leaving untouched the popular illusion that citizens were in charge of their destinies. Lippmann saw these deceptions as necessary for governance in the modern age, and in so contending he helped inspire, or at least "justify," the public relations/image manufacturing industries which constitute cornerstones of today's "hyperreality."

A major problem in openly constructing pseudoenvironments along the lines suggested by Lippmann, of course, concerns the distaste many Americans felt and feel regarding oligarchy and manipulation; as Lippmann remarked (1965): "The desire to be the master of one's own destiny is a strong desire" (p. 195). A second difficulty concerns incredulity of audiences. Better, then, to construct pseudoenvironments surreptitiously. One way of doing this is to incorporate into them the fiction that democracy persists, that people remain in control. It is in this context that the second generation media scholars, led by such towering figures as Paul Felix Lazarsfeld and Elihu Katz, can be viewed.

Lippmann was an advancement over the Chicago School in the sense that an at least truncated political economy formed a cornerstone of his media analysis. In his own way, however, Lippmann was every bit as naïve as Dewey; while convinced that cultures (pseudoenvironments) can and must be manufactured by elites to secure popular consent, until his later years Lippmann guilelessly presumed that the policies made possible thereby would be largely beneficent and centered on the common good. Only the prolonged war in Vietnam dissuaded him of that delusion (Blum 1984:9).

\section{Era of Movies and Broadcasting}

\section{The Empirical School}

Minimal Effects. The Chicago theorists' influence waned by the early 1930s. It became increasingly difficult to sustain a posture of inevitable progress through advancing technology in the face of World War I devastations, the use of media for advertising, public relations and propaganda, and the onset of the Great Depression. Not to be discounted, as well, was the impact of Lippmann's Public Opinion. Reviewing the book in 1922, Dewey himself declared: "The manner of presentation is so objective and projective, that one finishes the book almost without realizing that it is perhaps the most effective indictment of democracy as currently conceived ever penned" (Dewey 1922:286-88).

In the 1930s, therefore, born out of the government's psychological warfare activities of the First World War, a less idealistic, more pragmatic paradigm of media studies came to the fore. The emerging literature eschewed speculating on how media would contribute to community, democracy, enlightenment and human betterment, to 
focus instead on persuasion, psychological manipulation, and marketing. World War II, likewise, was a boon to the new breed of media scholars, many of whom were complicit with the U.S. government's propaganda activities during and continuing after that war. Simpson (1994) lists the following, among others, as eminent American communication/ media scholars working for or with the U.S. military on psychological warfare during World War II: Harold Lasswell, Hadley Cantril, Rensis Likert, Leonard Doob, Wilbur Schramm, Leo Lowenthal, Paul Felix Lazarsfeld, Frank Stanton, George Gallup, Elmo Roper, Ithiel de Sola Pool, Daniel Lerner, Edward Shils, Carl Hovland, Louis Gutman, Robert Merton (pp. 26-9) — a virtual Who's Who of American communication studies.

Given connections with the U.S.military, and their focus on persuasive communication, it might at first seem surprising that the sole media "law" these researchers devised was the "law of minimal effects," as "discovered" by Lazarsfeld. Arguably, his study, The People's Choice (Lazarsfeld, Berelson and Gaudet 1944) and its main finding concerning "minimal effects" responded, albeit implicitly, to (1) concerns raised by the Payne Fund Studies (1920s) on the deleterious effects of movies on children (sleep disturbance, negative influences on attitudes and behavior, emotional stimulation, presentation of nonmainstream moral standards), (2) continued overt domestic as well as foreign propaganda and psychological warfare, including but certainly not limited to Hitler's use of radio, loudspeaker, pageantry, film, art, sound and light shows to mesmerize a nation, and (3) the panic generated by Orson Welles's 1938 Halloween radio adaptation of "War of the Worlds." All these, were they not neutralized, could either undermine belief in the existence of American democracy in an age of media manipulation, or lead to restrictions on the freedom of media owners and advertisers, or both.

Paul Felix Lazarsfeld (1901-1976) was a Viennese social psychologist who emigrated to the United States in the 1930s. His major research interest was marketing, and he set up both the Princeton Office of Radio Research (1937) and the Columbia University Bureau of Applied Social Research (1939) to further his studies. Lazarsfeld's bureaus received funding from the Rockefeller Foundation which was used to launder funds from the CIA (Simpson 1994: 81), the radio networks, newspaper publishers, marketing firms, and polling companies. He and his associates investigated questions such as: audience demographics, satisfactions that audiences attain from radio, and correlations between audience tastes and social stratification. Large portions of Lazarsfeld's research was intended to aid media companies gain audiences and help advertisers and public relations firms become more adept at moulding audience tastes and opinions. Lazarsfeld was, then, an empirical social scientist whose mission was, one might say, to help elites structure Lippmann-style pseudoenvironments and ascertain how effective these were in affecting behavior and opinion. Indeed, Lazarsfeld (1941) coined the term, "administrative research" to denote the type of work he performed and to distinguish that from "critical research," [5] defined later in this paper. "More than anyone else," writes Czitrom (1982), "he [Lazarsfeld] shaped the field of communications research in the next decade" (p. 129). Hardt (1992) agrees: "Under Lazarsfeld's leadership communication research in the United States [became] a formidable enterprise which was deeply committed to the commercial interests of the culture industry and the political concerns of government" (p. 114).

The People's Choice, Lazarsfeld's seminal 1944 panel study, investigated voter intention and behavior in the context of election propaganda. Lazarsfeld et al claimed that "activation" of latent predispositions and "reinforcement" of preexisting attitudes were the main consequences of election publicity. Significantly, Lazarsfeld and associates maintained that only "conversion" from prior intentions should be considered important in terms of media effects, and since conversion was barely evident in the panel studies for the 1940 landslide presidential election (Roosevelt versus Wilkie) the authors concluded that media effects "are really quite limited" (Lowery and DeFleur 1988:102). For four decades thereafter, "'limited effects' was a major defense of owners of new media technologies, including television, from government regulation in the United States" (Chaffee and Hochheimer 1985:75).

In addition, in The People's Choice Lazarsfeld et al developed the "two-step flow" model of mass communication, elaborated later in Personal Influence by Lazarsfeld and Elihu Katz (1955). That model proposed that the attitudes of most people are not influenced directly by media, but rather by opinion leaders with whom they are in personal contact. Mainstream media scholarship built on that premise, modifying it however in distinctly antipolitical economy ways. Soon there appeared the multi-step model of diffusion, as forwarded by researchers such as Everett Rogers and Floyd Shoemaker (1971). The new model proposed that "the ultimate number of relays between the media and final receivers is variable" (Littlejohn:351), which is to say that general audiences were hypothesized as being even further removed from direct media influence than proposed by the two-step flow.

As well as suiting the needs of the broadcasting and motion picture industries, mainstream media scholarship helped assuage the democratic aspirations of the American citizenry. Even though millions of dollars were spent each year on media advertising and PR with the intent of affecting audience behavior and understanding, solace for 
democrats could found in the "law of minimal effects" and in the two-stage/ multi-stage flow: Citizens remained in charge of their destinies despite persuasion and attempted manipulation at every turn, they were told. The minimal effects model also played into the hands of U.S. foreign and trade policy in countervailing cultural protectionists around the world, including UNESCO; more on this below.

The People's Choice suffered from major methodological flaws, misconstruing "activation" and "reinforcement" as insignificant consequences of media exposure being but one: to reinforce the status quo and to generate active support in place of tacit approval are obviously desiderata from the standpoint of governing elites. Even more telling is the fact that a large proportion of the interviewees stated that media were the single most important influence on their voting intentions, not "opinion leaders," a finding that Lazarsfeld duly reported but overlooked in drawing conclusions. Perhaps most significantly, however, a "law" of media effects based on a panel study carried out in Erie county Ohio during a lopsided election campaign is, to say the least, overdrawn. Nonetheless, Lazarsfeld's conclusion remained for decades the received wisdom in media studies, with Joseph Klapper's The Effects of Mass Communication (1960) perhaps marking "the watershed" (Chaffee and Hochheimer 1985:95).

The "law of minimal effects" was, in effect, an umbrella term — a prophylactic - under which on-going research into how the public's beliefs and perceptions can be manipulated was carried out. Notable among that activity were Carl Hovland's experiments during and after the War, funded by the U.S. military and the Rockefeller Foundation. According to Lowery and DeFleur (1983), between 1946 and 1961 Hovland's research team conducted over fifty experiments regarding persuasive communication (p. 138). Significantly, in their commentary introducing this research to undergraduates four decades later, Lowery and DeFleur (1988), evidently without intended irony, assert:

Once new principles [of persuasion] were uncovered, they could then be used by pragmatic, innovative Americans to make a better world for everyone. ... There was much work to be done by social and behavioral scientists. The world was still filled with prejudice, discrimination, and bigotry. And now that nuclear weapons were a reality, the task of improving relationships between peoples seemed more urgent than ever. Badly needed, for example, was a better understanding of how people's beliefs, attitudes, and behavior could be modified in socially approved ways through carefully designed persuasive communication (p. 137).

Other mainstream research programs during this period pertained to content analyses of propaganda (Harold Lasswell), survey techniques and the measurement of public opinion (George Gallup, Elmo Roper), audience and market research (Lazarsfeld), and decision-making in small groups (Kurt Lewin). Although variegated, the research had commonalties: it was positivist and empirical, it was methodologically individualist, and it focused on means of changing attitudinal/behavior/belief. It was, one might say, in direct contradiction to the "law of minimal effects."

The "law of minimal effects" was belied not only by on-going research, but as well by practices and premises of media companies. Broadcasters sold advertising, for example, on the basis that "activation" was an important and sought after consequence of media exposure; corporations hired PR professionals to "reinforce" corporate images as well as to "convert" audiences during periods of crisis management- the Rockefeller interests' media activities following the Ludlow Massacre being seminal in this regard (Zinn 2005:355-57). From the 1930s through the 1960s, moreover, an intense multi-media campaign of anticommunist indoctrination was waged on domestic audiences by the U.S. government and media corporations, entailing censorships, persecutions of media celebrities and academics, and the production/distribution of anticommunist materials in the guises of entertainment and "news," all on the presumption that media have strong effects (Barson 1992; Schwartz 1998).

The period also saw the rise of an oppositional, albeit marginalized, communication scholarship. In 1948 Dallas Smythe began teaching the first course anywhere on the political economy of communication, although discretion dictated that for several years the course bear the title, "The Economics of Communications" (Lent 1995:43). In the course Smythe focused primarily on electronic communication-telegraph, telephone, radio broadcastingand on radio spectrum allocation. [6] His concerns were how these fields were organized, how they interrelated as industries, and the development of public policy, particularly at the domestic (American) level, but internationally as well (Smythe 1957). Over time Smythe was joined at Illinois by critical scholars George Gerbner (in 1956) and briefly by Herbert Schiller (in 1960), and a coherent, oppositional, albeit marginal, American critical media studies scholarship was born. Gerbner, particularly, challenged directly the "law of minimal effects." He maintained that in contemporary society people attain their identities not from their families, schools, churches and communities, but from "a handful of conglomerates who have something to sell." He claimed further that people who watch large amounts of television are more likely to believe that the world is mean and violent, and he backed these contentions up with prodigious empirical studies (Morgan 2002). In congressional testimony of 1981 he summarized: "Fearful 
people are more dependent, more easily manipulated and controlled, more susceptible to deceptively simple, strong, tough measures and hard-line postures. They may accept and even welcome repression if it promises to relieve their insecurities. That is the deeper problem of violence-laden television." (Associated Press 2006:B4).

Uses and Gratifications. Although the "minimal effects" model declined by the 1960s due to methodological problems, conflicting evidence (such as provided by Hovland and Gerbner), and overdrawn conclusions, another theory, namely "uses and gratifications," that had been waiting in the wings since the 1940s promptly took its place, becoming "one of the most popular theories of mass communication" (Littlejohn:364). [7] As noted by Wimmer and Dominick (2005), uses and gratifications focused attention on audience members, as opposed to message senders (chap. 18), or indeed for that matter on messages (Littlejohn:364). Christopher Simpson attributes the rebirth of "uses and gratifications" to a 1959 paper by RAND Corporation researcher, W. Phillips Davison (Simpson:91); in any event, by 1968 and publication of Television in Politics: Its Uses and Influences by Blumler and McQuail, "uses and gratifications" was mainstream.

Unlike minimum effects, "uses and gratifications" did not deny the possibility of profound consequences of media on audiences; what it asserted, rather, was that consequences are anticipated and actively sought out by audiences in light of preexisting needs and desires (Katz and Gurevitch 1974:12). Once again, audiences remain in control, at least according to mainstream theory, obviating concerns regarding the machinations of message senders.

Sponsors of research into persuasive communication, however, understood "uses and gratifications" at a more pragmatic level, of course. To affect or control public attitudes and behavior, message senders (molders of pseudoenvironments) must first offer audiences something they need or desire. According to the "uses and gratifications" school, uses of television programming, for example, include: attaining information, gaining a sense of personal identity (as through role modeling), facilitating social interaction, and being entertained (Chandler 1994). Each of these "uses," however, has major, albeit under-emphasized, even unacknowledged, political economy implications: "Attaining information," for example, undoubtedly a goal of newspaper readers and many television viewers, begs the question of what news /information is made available to these inquiring minds and what is notquestions addressed with telling results in analyses of news content by such marginalized political economists as Edward S. Herman and Noam Chomsky (1988). As Walter Lippmann (1965) remarked, "News and truth are not the same thing, and must be clearly distinguished; the function of news is to signalize an event, the function of truth is to bring to light the hidden facts..." (p. 226). One of the factors causing a disparity between news and truth, Lippmann (1965) proposed, is the control exercised over reporters by media owners (p. 227), who in turn are responsive to desires of advertisers, both individually and as a system. Decades after Lippmann's Public Opinion was published, Chomsky and Herman denoted advertiser control as one of four "filters" through which news must pass prior to publication. All these areas and more that are of concern to political economists, are obscured by focusing merely on "uses and gratifications" of audiences, and by implication on the "sovereignty" of media "consumers." [8]

Likewise, "attaining a sense of personal identity," another "use and gratification," is loaded with unacknowledged political-economic import. It is surely a goal of much advertising to set forth models of comportment; when audiences seek out and find role models in the media, they become complicit to their own political-economic control—the very definition of hegemony. Critical researchers, George Gerbner and associates, in responding with "cultivation research," demonstrated "how exposure to the world of television contributes to viewers' conceptions about the real world" (Shanahan and Morgan 1999:7). For Gerbner, cultivation was all about social control by elites to benefit elites. Cultivation studies constituted, in essence, empirical analyses of the successes/limitations of Lippmann-styled pseudoenvironments. Gerbner's major finding was that heavy users of the medium are more likely to accept as real television's depiction of social life than are light users.

From a "uses and gratifications" perspective, audiences also use media to provide bases for conversation and social interaction, or use media as a substitute for real-life interactions (Chandler 1994). From a political economy perspective, however, as Walter Lippmann emphasized, it is very much in the interest of elites that the general public interpret the social, political, and economic environment in ways conducive to preserving and extending elite authority, and one marvelous way of instituting this form of social control is by providing topics for daily conversation (an O.J. Simpson or Michael Jackson trial, say, or continually fretting over "weapons of mass destruction"). Even better, however, is if audiences forego conversations altogether, and rely instead on media "friends" for their "socializing." Near the end of his life, war time propagandist John Grierson (1979) reflected on the immense propaganda potential of television, coupling as it does the audience's desire to be "cozy" with immense powers of suggestion: "Where 
more notably than in the home does the power of suggestion operate?” Grierson asked (pp. 210-19).

Active audiences. Although "uses and gratifications" peaked by the $1980 \mathrm{~s}$, it may be thought of as constituting but one stream of a much broader and still contemporary antipolitical economy doctrine, namely the "active audiences." In the opening chapter of the revised edition of The Process and Effects of Mass Communication, Schramm (1971) immodestly claimed that he had been first, way back in 1952, to suggest that audiences are "highly active, highly selective ..., manipulating rather than being manipulated by a message — a full partner in the communication process." Schramm added that his original article, "How Communication Works," was intended to be "a reaction against ... the irrational fears of propaganda being expressed in the early 1950s." He continued:

The unsophisticated viewpoint was that if a person could be reached by the insidious forces of propaganda carried by the mighty power of the mass media, he could be changed and converted and controlled. So propaganda became a hate word, the media came to be regarded fearfully, and laws were passed and actions taken to protect "defenseless people" against "irresistible communication" (Schramm 1971:8). [9]

Schramm is as much as admitting that his research program was designed to neutralize or abolish the political economy of media.

The doctrine of active audiences expanded significantly over ensuing years — to such a point, indeed, that according to some contemporary proponents everyone is capable of construing his or her own meanings from media texts (Fish 1980; Easthope 1991:47-51). Media presentations for active audience theorists are likened to Rorschach tests. As Paul Cobley (1996) summarizes:

The crux of the issue is whether there are as many possible readings of a text as there are readers, or whether there may be a small number of 'correct' or 'legitimate' readings of a text (or even just one 'correct' reading). ... For [Stanley] Fish, the reader supplies everything; this is because there can be nothing that precedes interpretation. As soon as human beings apprehend an item in the world they have already embarked on a process of interpreting it. There can be no 'given' as such (pp. 405-406).

Emphasizing active audiences, again, reduces the possibility of political economy for, as the Mattelarts ask, "What is the point in dwelling on unequal exchange of television programes and films on the international audiovisual market if the power of meaning lies in the hands of the consumer?" (Mattelart and Mattelart 1995:125).

Like "uses and gratifications," the doctrine of the "active audience," too, can be modified to become compatible with political economy, even though mainstream proponents failed to do this. In England, Stuart Hall, however, suggested that the "codes" readers bring to texts are as important as the texts themselves and that codes are class or subculturally based. Hall (1980) did not dispute that there is a dominant meaning (a "preferred reading") to texts; to the contrary, he maintained that meanings are to be struggled over and thereby he related codes or "readings" to political economy.

\section{Media Transfer Model}

In official policy circles, the United States for decades has championed international "free flow" of information, albeit a "free flow" encumbered by stringent copyright, and has justified that position with two principal contentions. First, it has claimed that "free flow" of information and individual liberty in accessing informational artifacts are the sine qua non of democracy and of individual liberty/human rights; emerging media, viewed from this perspective, are "technologies of freedom" (Pool 1990), certainly not instruments of oppression, domination, empire, and control. Second, in international fora, the United States claims that informational artifacts are, and should be recognized as being merely economic commodities, produced and consumed for no other purposes than to satisfy consumer wants ("consumer sovereignty") and to earn pecuniary rewards for rights' holders; hence, these artifacts are/should be subject to international trade rules as enforced by the World Trade Organization and other bi-lateral/multilateral trade arrangements, as opposed to policies of cultural organizations like UNESCO (Braman 1990).

It is evident that the "law of minimal effects" and the doctrine of "active audiences" (if devoid of political economy interpretations like those formulated by Stuart Hall), if accepted, could go a long way to counter international concerns over America's media dominance. Even more effective, though, would be a doctrine positively promoting global media expansion. Such was the political-economic import of the "media transfer model" as developed and promoted by luminaries bankrolled by the U.S. military and CIA [10] like Elihu Katz, Wilbur Schramm, Lucien 
Pye, and Ithiel de Sola Pool. [11] MIT's de Sola Pool (1966), for example, insisted that "where radio goes, there modernization attitudes come" (pp. 106-110). Radio audiences in Third World countries, according to these theorists, after being continually exposed to western media, will wish to imitate modern (i.e., western) attitudes and behavior and to cast off obsolete indigenous customs that inhibit economic expansion. The loss of customs and traditions that this entails is much to be desired, in the view of these scholars. Alienation and dislocation, loss of referents, social and cultural upheaval, loss of sovereignty and extension of American influence were concomitants largely unmentioned by these media transfer theorists (Sussman and Lent 1991:5-6).

More recently, in a rare but deservedly renowned public utterance, State Department officials cast a rather different light on America's cultural exports and by implication on the media transfer model. Characterizing media exports as "soft power" (defined as "the ability to achieve desired outcomes in international affairs through attraction rather than coercion") Nye and Owens (1996) deemed soft power to be as important as armaments in America's quest for world domination, [12] perhaps explaining, too, why so much of the innovation in communication media over the past hundred years—-radio transmissions, satellites, computers, the internet—is traceable to the U.S. military (Mattelart 1994).

Controversies surrounding "free flow" vs. "cultural imperialism" are, of course, decades' old (Nordenstreng and Schiller 1979; UNESCO 1980), even leading the United States and the United Kingdom to withdraw for a time from UNESCO (Preston, Herman and Schiller 1989) as they were losing the battle there, to fight their cause instead in international trade fora such as the World Trade Organization. This is not the place to recount those prolonged and bitter disputes, except to note that the disagreements persist to the present: Virtually unilaterally in October 2005 the United States argued and voted against UNESCO’s Convention on Cultural Diversity (Choike 2005).

\section{Cultural Studies/ Social Construction}

From the beginning, through foundational texts by writers like E.P. Thompson, Raymond Williams, and Stuart Hall, political economy was a mainstay—even the driving force—of British cultural studies (Turner 1990:41-84; Sardar and Van Loon 1999:58). Likewise did foundational Canadian cultural/media theorists, beginning with Harold Innis who linked time/space bias of media with monopolies of knowledge, emphasize political-economic aspects of culture (Innis 1951, 1952; Babe 2000). However, as Sardar and Van Loon (1999) remark, "Questions of power and politics, class and intellectual formation, so fundamental to the British exponents of cultural studies, lost their significance in the United States" (p. 58).

Intellectual historian Richard E. Lee (2003) dates the inception of American cultural studies to a 1966 international conference at John Hopkins University entitled, "Criticism and the Sciences of Man/Les Langages Critiques et les Sciences de Homme" (p. 153). It was there that Paul de Man (1919 - 83), then newly arrived at Yale, met Jacques Derrida, and the Yale School of deconstruction was born. [13] Deconstruction, through de Man's influence became "profoundly conservative" (Lee:156). For de Man and the Yale poststructuralist movement, there were "no facts, only interpretations; no truths, only expedient fictions," and these axioms were applied not only to literature but to the human sciences (Lee:154). The impossibility of political economy, given such presuppositions, is readily apparent. We see here also a convergence between poststructuralist cultural studies and the doctrine of the active audience/active reader in media studies. These trends are discussed further in the next section.

Simultaneous with the John Hopkins conference, yet another scholarly discourse of relevance here was being inaugurated with publication of Peter Berger and Thomas Luckmann's highly influential text, The Social Construction of Reality (1966). I take the Berger-Luckmann text as an instance also, in part, of symbolic interactionism, as developed by Herbert Blumer and others. A main difference between the "active audience" thesis discussed above and the Berger-Luckmann position, is methodological individualism versus methodological collectivism. For the former, individuals negotiate their meanings from stimuli provided by message senders; for the latter, meaning is a matter of social conditioning. With regard to obscuring political economy, however, these two mainstream models are cut from the same cloth.

"Common sense," or everyday reality, Berger and Luckmann (1966) wrote, seems (erroneously) to be objectively given (pp. 35-7). They added significantly: "While I am capable of engaging in doubt about its reality, I am obliged to suspend such doubts as I routinely exist in everyday life" (Berger and Luckmann:37). One of the factors making every day life seem to be given objectively is language. Language originates in and refers primarily to every day life and as a sign system it has the "quality of objectivity," or given-ness (Berger and Luckmann:53). They remark that language is in fact, however, a "repository of vast accumulations of meaning and experience, which it can then 
preserve in time and transmit to following generations" (Berger and Luckmann:52); language in its seeming givenness, they continue, has a "coercive effect," "forcing" people into its patterns (Berger and Luckmann:53). These are insightful statements, possessing much potential in terms of political economy. The idea that members of a society or community are influenced, largely unconsciously, by the "biases" of the language system they are born into is a far cry, it may be noted, from the autonomy proposed by the "active reader" thesis. One wishes that Berger and Luckmann had gone on to explore manifestations of the control or influence different groups exercise through their control of or influence over language; unfortunately, that door they failed to budge.

They continued that language is not only a sign system that re-presents objects of everyday life, it is also a symbol system that transcends everyday existence: "Language constructs immense edifices of symbolic representation that appear to tower over the reality of everyday life like gigantic presences from another world. Religion, philosophy, art, and science are the historically most important symbol systems of this kind" (Berger and Luckmann 1966:55). Here again is presented a gaping entrance to political economy, but Berger and Luckmann (1966) pass by hurriedly, choosing rather to personify language and to use the passive tense, thereby de-politicizing their thesis, as in the following extract:

Language builds up semantic fields or zones of meaning that are linguistically circumscribed. Vocabulary, grammar and syntax are geared to the organization of these semantic fields. Thus language builds up classification schemes to differentiate objects by 'gender' (a quite different matter from sex, of course) or by number; forms to make statements of action as against statements of being; modes of indicating degrees of social intimacy, and so on (p. 55).

Also giving an illusion of given-ness to everyday life, according to Berger and Luckmann (1966), are institutions: "The institutional world," they write, "is experienced as an objective reality. It has a history that antedates the individual's birth and is not accessible to his biographical recollection" (p. 77). Unfortunately Berger and Luckmann refrained from concrete, historical analyses of the rise of institutions, declaring rather that institutions arise out of the "reciprocal typification of habitualized actions by types of actors" (Berger and Luckmann:72). Indeed, they proposed a Robinson Crusoe situation, comprised of A and B:

As A and B interact, in whatever manner, typifications will be produced quite quickly. A watches B perform. He attributes motives to B's actions and, seeing the actions recur, typifies the motives as recurrent. As B goes on performing, A is soon able to say to himself, 'Aha, there he goes again.' At the same time A may assume that B is doing the same thing with regard to him. From the beginning, both A and B assume this reciprocity of typification (Berger and Luckmann:74).

It would, in brief, be difficult to conceive of a more power-neutered account of the rise of institutions and cultural practices than this.

To summarize, Berger and Luckmann created openings through which political-economic understanding could have infused American communication and cultural studies, but they papered over these openings, obscuring them for many readers. Moreover, in proposing that reality is and can be nothing but a "social construction," they denied solid ground from which to critique common or popular understanding, and thereby undermined the ontological premise of critical theory. [14] Whereas Lippmann insisted that there is a material reality, understandable in their narrow fields by experts, Berger and Luckmann proposed that this is not so. In effect, they avoided a criticism concerning elite dishonesty that could (and should) be leveled at Lippmann who had urged elites to construct pseudoenvironments to gain popular acceptance for their policies. For Berger/Luckmann, "pseudoenvironment" has no meaning as "reality" is merely a social construction in any event. Conservative postmodernist/poststructuralist theorists like Paul de Man, Stanley Fish and Jean Baudrillard, I will argue below, implicitly took Berger-Luckmann to the next step-the denial even of socially constructed reality.

To summarize, although there were remarkable changes in the modes of communicating from the early $1900 \mathrm{~s}$ to, say, the 1980s, accompanied by equally momentous changes in media theorizing by mainstream American scholars defined here as writers most frequently cited in histories of media/communication thought, there was at least one notable constancy: the avoidance of political economy. To avoid political economy in media scholarship is to draw attention away from disparities in communicatory power and from uses to which that power is put. Some of the theorists reviewed here may honestly have believed that these issues are insignificant; others may, perhaps, more consciously have played into the hands of powerful message senders. Irrespective of motivation, the consequence in each case has been the same: mainstream American media scholarship, by and large through neglect or inattention, "justified" gross disparities in communicatory power. The next section carries the story into the present, the era of 
ast capitalism and the accompanying postmodernist discourses.

\section{Digitalized Media and the Age of Fast Capitalism}

\section{Digitization and the Information Society}

According to many commentators, computer communications has created a brand new era, one that is as distinct from the age of broadcasting as that was from the age of print. Information Society, Information Economy, Postindustrial Society, Third Wave, Network Society are but some of the terms still circulating to distinguish the present era of "fast capitalism" from what existed before.

Claude Shannon and Warren Weaver were among the early theorists of digital communication. In 1949, within Bell Labs and for the U.S. military, they devised the "mathematical theory of communication." They denoted the "quantity" of information as the number of binary digits (on-off pulses or "bits") needed to specify any given selection from a preset field of possibilities (Shannon and Weaver 1949). The digitization of communication as we understand the term today, however, certainly surpasses Shannon and Weaver's modest expectations. Any and all information that could previously be transmitted electronically (text, image, sound, moving picture) can now be transformed for purposes of transmission into binary sequences.

Katherine Hayles (1999) attributes to Shannon and Weaver the conceptualization, common today, of information "as an entity distinct from the substrates [or media] carrying it" (p. xi). Hayles proposed that from Shannon and Weaver's formulation, it "was a small step to think of information as a kind of bodiless fluid that could flow between different substrates without loss of meaning or form." This is because any sequence of $1 \mathrm{~s}$ and $0 \mathrm{~s}$, or on-off pulses, can be replicated so easily that the substrate or carrier seems to lose significance in comparison to the sequence itself.

At the very time Shannon and Weaver were theorizing digitization, other scholars were indeed "de-materializing" information along the lines suggested by Hayles. In The Human Use of Human Beings (1950), for instance, cyberneticist Norbert Wiener (1894 - 1964), a former professor of Claude Shannon, maintained that organisms can be viewed metaphorically as messages and as patterns, which is to say as recurring forms; only secondarily are they material. In an elegant, almost rhapsodic passage, Wiener (1950) described how much more important, or at least fundamental, pattern is compared to matter:

Life is an island here and now in a dying world. The process by which we living beings resist the general stream of corruption and decay is known as homeostasis. ... It is the pattern maintained by this homeostasis which is the touchstone of our personal identity. Our tissues change as we live: the food we eat and the air we breathe become flesh of our flesh and bone of our bone, and the momentary elements of our flesh and bone pass out of our body every day with our excreta. We are but whirlpools in a river of ever-flowing water. We are not stuff that abides, but patterns that perpetuate themselves (p. 130).

What Wiener downplayed, of course, was not only the material constituting the forms, but also the matter-energy foundation that gives rise to the possibility of homeostasis.

Economist Kenneth Boulding, a contemporary of Wiener, went even further. He minimized the material aspect of information to such an extent that he claimed "information" defies the laws of physics, specifically the first and second laws of thermodynamics. Regarding the first law, the law of conservation, he maintained that information/ knowledge alone is what can really increase, making it "primal" to evolutionary processes:

The through-put of information in an organization involves a "teaching" or structuring process which does not follow any strict law of conservation even though there may be limitations imposed upon it. When a teacher instructs a class, at the end of the hour presumably the students know more and the teacher does not know any less. In this sense the teaching process is utterly unlike the process of exchange which is the basis of the law of conservation. In exchange, what one gives up another acquires; what one gains another loses. In teaching this is not so. What the student gains the teacher does not lose. Indeed, in the teaching process, as every teacher knows, the teacher gains as well as the student. In this phenomenon we find the key to the mystery of life (Boulding 1956:35).

And again, the same thought, expressed twenty years later:

Knowledge ... is the field within which evolution takes place. It is the only thing that can really change, the only thing that is not conserved (Boulding 1978:224).

A further implication of the purported capacity of information/knowledge to defy or transcend the law of conservation (if true), is the inapplicability of the law of entropy. In fact, Boulding saw information as a force countering entropy. 
Another eminent scholar who celebrated the purported immateriality of information was Ithiel de Sola Pool. In his last major text, Pool (1990) declared:

In a world of scarce resources, thought is pleasingly abundant; like air, it is a free good. ... Communication, in short, is one of the good things in life that can be had without straining the world's scarce resources. In communication we are very far from the limits of growth (p. 220).

Likewise John Perry Barlow (1996), in an influential essay, proposed that internet "space" is fundamentally unlike the material territories governed by nation states, writing:

Cyberspace consists of transactions, relationships, and thought itself, arrayed like a standing wave in the web of our communications. Ours is a world that is both everywhere and nowhere, but it is not where bodies live. We are creating a world that all may enter without privilege or prejudice accorded by race, economic power, military force, or station of birth. We are creating a world whereanyone, anywhere may express his or her beliefs, no matter how singular, without fear of being coerced into silence or conformity.

These are but a few of many possible citations. For the present discussion, their importance lies in the support they lend to the (often implicit) premise of some postmodernist/poststructuralist theorists regarding the immateriality of information/knowledge, a view that has gathered momentum in recent decades.

In some ways the "dematerialization" of information dates back also to the semiotics of Ferdinand de Saussure at the turn of the last century. De Saussure declared that all "signs" (or in our terms, "information") consist of two elements, the signifier, the physical presence of the sign, and the signified, the mental image summoned by the signifier for the person perceiving it. De Saussure, a linguist, maintained that signifieds are contingent largely on the structure of language, and very loosely if at all on the objects in the external world to which signs ostensibly point. In other words, the materiality in de Saussure's system consisted mainly of the physical presence of signs, not the external worlds to which they ostensibly refer; it is that minimal material grounding that writers like Wiener further trivialize. It is with this background that we come to recognize what I would term the dialectic of postmodernist discourses.

\section{The Complexity of Postmodernism}

Arguably postmodernist thought is the emerging ontology of our era of fast capitalism. Without question, fast capitalism depends on digitization of information flows, and equally unquestionably digitization is the technology that best suits postmodernist thinking, since so much can be done through computers to alter representations and create simulacra.

In his review of postmodernist thought, Frank Webster detected several key features. Of greatest significance, however, he declared, is an insistence that we live in a world of signs. "Symbols and images," he continued, for many postmodernists "are the only 'reality' that we have; we do not, in other words, see reality through language; rather language is the reality that we see” (Webster 1995:175). Or, as Frederic Jameson (1991) put it:

Postmodernism is what you have when the modernization process is complete and nature is gone for good. It is a more fully human world than the older one, but one in which "culture" has become a veritable second nature" (p. ix).

By emphasizing culture and language as makers of "reality," or as the unavoidable lens through which the outside world is interpreted, postmodernists challenged the objectivity of the "truths" proposed by Enlightenment rationality. Their discourses arose, however, not merely in response to recognition of the problematic nature of language with regard to mapping external reality (de Saussure's point), nor simply to account for ongoing changes in social organization as induced by changes in media of communication ("the mode of information") (Poster 1990), but also, often, out of deep-seated dissatisfactions with what went before, namely Enlightenment thinking and harmful consequences stemming from that: weaponry, class injustices, individualism, utilitarianism and the concomitant breakdown of community, environmental despoliation, and so on. Of course long before postmodernist writers came on the scene, the Enlightenment project of knowledge for power had critics: Marx criticized the injustices of Baconian instrumentalism and rationality, Durkheim the anomie, and Thoreau the environmental degradation. In a sense, however, postmodernist thought is, or can be, even more fundamental and far-reaching in its critique than what was launched by those writers. For what postmodernist thought does, in part, is to challenge Baconian rationality and empiricism at the core. This critique, already implicit in the linguistics of de Saussure, has been ramped up several 
levels with electronic communication generally, and digitization in particular. According to Poster (1994), Language no longer represents a reality, no longer is a neutral tool to enhance the subject's instrumental rationality: language becomes or better reconfigures reality. ... Electronic communication systematically removes the fixed points, the grounds, the foundations that were essential to modern theory (p. 176).

What this means, in terms of political economy, is that all of the events presumed by Enlightenment thinkers to be attributable to "nature," or to "external conditions" (think of gender and sexuality, for example, or of race and ethnicity, or of Malthus, Herbert Spencer and Darwin), are "really" a consequence of culture and language. It is the culture, and the biases of language that are the culprits, not some external "law" of nature termed the "Principle of Natural Selection," "The Survival of the Fittest, "The Principle of Population," or marketplace quests for "efficiency" (Babe 1995). It is hard to envisage a more fundamental critique of the existing order. It was also Macpherson's point, however, as elaborated above and at length in this paper, that mainstream thought tends very much to support or justify established power. It would then follow that as postmodernist/poststructuralist thinking moves increasingly into the mainstream, one can anticipate it losing its critical edge and becoming a paradigm that "justifies" fast capitalism. Indeed, I would argue, trends toward the domestication of postmodernist thought are not only evident, but are inherent to the enterprise itself.

\section{The Dialectic of Postmodernism}

On the one hand, postmodernist discourses undermine the Enlightenment project, perhaps more thoroughly than any other critique yet launched. If "reality" is merely a product of language, whose signs are ever shifting in meanings as new digitized forms continually refer sequentially to one another with little correspondence to the "real world," then the categories "realists" have taken for granted—capital and labor, progress, gender, ethnicity, intelligence, rationality, sanity, and on and on-categories that in their seeming "givenness" have often "justified" outcomes like those bemoaned by writers like Marx, Durkheim and Thoreau-are now seen as mere linguistic constructions, with no authenticity outside of language, which is itself an artifact not unrelated to the distribution of power. By this understanding of postmodernist discourses, there is a ready alignment with political economy as language and culture become sites of struggle.

On the other hand, the seeds of the destruction of postmodernists' radical bent are readily evident. First, if "reality" is indeed merely a fabrication of language, then one might conclude that the concerns, as raised by Marx, Durkheim, Thoreau and their successors are likewise mere linguistic fabrications, mere "phantasmagoria," bearing no necessary relation to material existence. Indeed, the very criteria whereby social arrangements are to be judged (equity, human dignity, environmental health, peace), become mere linguistic constructs. As Frank Webster (1995) remarks, "Postmodernists' emphasis on differences—in interpretation, in values—is in close accord with the abandonment of belief in the authentic" (p. 173). Quoting Michel Foucault, he adds, "Postmodernists believe that 'each society has its regime of truth, its general politics of truth: that is, the types of discourse which it accepts and makes function as true.' In such circumstances postmodern thinkers perceive themselves to be throwing off the straitjacket of Enlightenment searches for 'truth', emphasizing instead the liberating implications of differences of analysis, explanation and interpretation" (Webster:167-8). But, it is hard to do political economy if one is not merely pointing to, but is actually celebrating differences in analysis, in explanation, and in interpretation. Indeed, from this postmodernist perspective, political economy is but one more of the "grand narratives" to be dismissed.

Second, postmodernist thought, if bereft of political economy considerations regarding power centers structuring language, controlling messages, and censoring messages, in effect takes the position that "pseudoenvironments" (or, in Jean Baudrillard's term, "simulacra") are all there is and all there can be. Lippmann, one senses, would have been delighted. The PR agencies and other spinners and fabricators are now absolved from not only of the intent to deceive, but from deception as well.

This "dialectic of postmodernist thought" is well illustrated by comparing the early and late writings of Baudrillard (1929 - present). According to Poster (2001), Baudrillard initially set out to "extend the Marxist critique of capitalism to areas that were beyond the scope of the theory of the mode of production;" later, he abandoned Marxism, however, to take up a "semiological model [as a way to] decipher the meaning structure of the modern commodity" (p.1). Ensuing from this transition, Poster (2001) advises, Baudrillard developed the notion of "'hyperreality' [as] the new linguistic condition of society, rendering impotent theories that still rely on materialist reductionism or rationalist referentiality" (p. 2). In brief, Baudrillard was initially a materialist grounded in the Marxist tradition, albeit one endeavoring to extend that tradition to encompass the consumer society, and ended up as a postmodernist for 
whom materialist explanations were "impotent." Let us, therefore, look more closely at these "two Baudrillards."

In "The System of Objects," Baudrillard insisted on maintaining a constant awareness of the materiality within which signs circulate. He did this in two ways. First, he related advertiser- induced meanings for products to social standing and power relations and maintained that this was the distinguishing feature of our consumer society compared to all others: "Undoubtedly, objects have always constituted a system of recognition," he wrote, "but in conjunction with, and often in addition to, other systems (gesture, ritual, ceremonial, language, birth status, code of moral values, etc.). What is specific to our society is that other systems of recognition are progressively withdrawing, primarily to the advantage of the "code of social standing"' (Baudrillard 2001:22). Indeed, he goes further: "Consumption is not a passive mode of assimilation and appropriation. ... Consumption is an active mode of relations (not only to objects, but to the collectivity and to the world), a systematic mode of activity and a global response on which our whole cultural system is founded" (Baudrillard 2001:24).

Second, he proclaimed, behind this "code of social standing" as manifested by owned and displayed commodities, lies "illegible" but nonetheless "real structures of production and social relations" (Baudrillard 2001:24). We may think we understand social relations by "reading" commodities, but that, he implied, masks the real relations of production and of social existence. For example, designer footwear may indicate wealth and create status for the wearer, but invisible are the Third World factories and the near-slave labor used in their manufacture, and as well the terms of trade that exist between the rich North and the "developing" South. Baudrillard (2001) added, "If the code's coherence provides a formal sense of security, that is also the best means for it to extend its immanent and permanent jurisdiction over all individuals in society" (p. 23).

Likewise, in "Consumer Society," he declared that while commodities appear to be self-generating-"a proliferating vegetation" - one must always remember that "they are in actuality the products of human activity, and are controlled, not by natural ecological laws, but by the law of exchange value" (Baudrillard 2001:33). The early Baudrillard, then, although postmodernist due to his emphasis on the centrality of signs and language, was not at risk of perhaps inadvertently supporting inequalities in the distribution of power, because he always bore in mind "the political economy of the sign" (Baudrillard 2001:60-100).

Baudrillard's materialist grounding disappeared, of course, in his perhaps most famous work, Simulations, and with it vanished political economy and the possibility of the critique of power. There Baudrillard maintained that in a world of circulating signs our condition is more one of simulation than it is of representation, which is to say signs

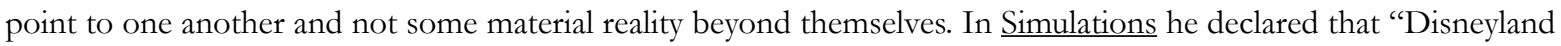
is presented as imaginary in order to make us believe that the rest is real, when in fact all of Los Angeles and the America surrounding it are no longer real, but of the order of the hyperreal and of simulation"(Baudrillard 1983:25). [15]

When the real and the fictitious, the objective and subjective, become merely "entangled orders of simulation ... a play of illusions and phantasms" (Baudrillard 1983:23), there is little possibility for political economy. Baudrillard (1983) himself recognized this, writing: "Power, too, for some time now produces nothing but signs of its resemblance ... Power is no longer present except to conceal that there is none" (pp. 45, 46). He continues:

Is any given bombing in Italy the work of leftist extremists, or of extreme right-wing provocation, or staged by centrists to bring terror into disrepute and to shore up its own failing power, or again is it a police-inspired scenario in order to appeal to public security? All this is equally true, and the search for proof, indeed the objectivity of the fact does not check this vertigo of interpretation. We are in a logic of simulation which has nothing to do with a logic of facts and an order of reasons. (Baudrillard 1983:31).

If the reality principle is in its death throes, and the "vertigo of interpretations" now dwarfs facts, how can one possibly pursue justice? It would make much more sense simply to luxuriate in the consumer society and forge whimsical interpretations of media-concocted phantasms-according to Frank Webster (1995) a common postmodernist recommendation (pp. 167-8).

On the other hand, James Compton (2004) insists and as the early Baudrillard (among others) showed, it is possible to write postmodernist analyses emphasizing the centrality of the sign from a materialist ground, thereby maintaining the possibility of political economy. I would argue that, in our globalizing era of augmenting gaps between rich and poor, environmental degradation and accelerating species extinctions, declarations of war under the cover of carefully contrived pseudoenvironments or simulacra, maintaining a material grounding to all our discourses is more important than ever.

Baudrillard's notion of the simulacra is Walter Lippmann's dream come true. For if non materialist postmodernists, 
such as Baudrillard, can convince the general public that simulacra is all there is, all they can experience, then Lippmann's elites will have even fuller reign. In the end, whatever he himself may think about his own purportedly "critical" stance, Baudrillard plays into the hands of authoritarianism.

In this brief overview of aspects of intellectual history we have discovered several seeming ironies or paradoxes: mainstream U.S. communication studies was born out of CIA and military funding, but issues of communicatory power (political economy) were continuously ignored in the mainstream literature; eminent media scholars engaging in psychological warfare and media propaganda avowed allegiance to a "law of minimal effects"; America's most distinguished journalist self-avowedly attempted to save democracy by counseling elites to manufacture pseudoenvironments; authors proclaimed in their books that authors provide little more than Rorschach tests for their readers. In such a bizarre context, is it so hard to accept that Baudrillard, ostensibly positioning himself as an egalitarian striking out at authority, in fact reduces the accountability with which power is wielded? Or that in being supercritical, he effaces the possibility of critical thought?

\section{Endnotes}

1. Many thanks to Ben Agger, Edward Comor and James Compton for helpful comments on a previous draft.

2. It has been suggested that Jacques Derrida, for instance, established deconstruction of texts as a means of opening texts up to new understandings, not just dominant interpretations. See O'Donnell 2003: 56.

3. Regarding the United States the Trilateral report declared: "Some of the problems of governance in the United states today stem from an excess of democracy ... Needed ... is a greater degree of moderation in democracy. In practice, this moderation has two major areas of application. First, democracy is only one way of constituting authority, and it is not necessarily a universally applicable one. In many situations the claims of expertise, seniority, experience, and special talents may override the claims of democracy as a way of constituting authority. ... Second, the effective operation of a democratic political system usually requires some measure of apathy and noninvolvement on the part of individuals and groups. In the past, every democratic society has had a marginal population, of greater or lesser size, which has not actively participated in politics. In itself, this marginality on the part of some groups is inherently undemocratic, but it has also been one of the factors which has enabled democracy to function effectively. Marginal social groups, as in the case of the blacks, are now becoming full participants in the political system. Yet the danger of overloading the political system with demands which extend its functions and undermine its authority remains." (pp. 113 - 14).

4. According to The Globe and Mail, "The Department of Homeland Security, along with the Patriot Act, has effectively suspended the rule of law in the United States-citizens can now be searched or arrested without a warrant, imprisoned without trial, tried by secret military tribunal, tortured or executed in secrecy. Their phones can be tapped, mail read, Internet monitored, and what they read at or borrow from the library can be analyzed for signs of deviancy. The guarantees of personal liberty in the Constitution have been trampled over. Between 30,000 and 40,000 people have been detained or harassed under the Patriot act, and precious few charges involving actual terrorism have been laid as a result." Paul William Roberts, "The Flagging Empire," The Globe and Mail, 10 September 2005, pp. F1 - F5.

5. The term, "critical," was actually coined in 1937 by Max Horkheimer in an article entitled, "Traditionelle und Kritische Theorie;" see Rogers 1994: 110.

6. Spectrum management for Smythe was "no sterile, neutral process." "It is," he insisted, "political in every sense of the word. ... The radio spectrum is to telecommunications as is water to fish, soil to plants." (Smythe 1985: 439).

7. "Uses and gratifications" had actually constituted a portion of Lazarsfeld's audience research; this was intended to aid media in gaining audiences.

8. The ideology of "consumer sovereignty" is a direct link to another depoliticized mainstream discourse, namely neoclassical economics. Unfortunately further elaborating the similarities between these mainline disciplines, while of interest and importance, is beyond the scope of this paper. See, however, Babe 1995 and Babe 2006.

9. Schramm's original 1954 edition of The Process and Effects of Mass Communication, of which "How Communication Works" is the opening chapter, "originated in the United States Information Agency's (USIA) need for a book of background materials which could be used in training some of the agency's new employees in the field of research and evaluation." See Schramm 1954. "Foreword," The Process and Effects of Mass Communication, Urbana: University of Illinois Press, 1954.

10. Ithiel de Sola Pool, Daniel Lerner and Wilbur Schramm, all exponents of the "media transfer model," for decades undertook research work and publication for the CIA through the CIA-funded Center for 
International Studies at MIT. Wilbur Schramm, by Everett Rogers's account "the" founder of US media/ communication studies, was also a part-time CIA campus informant; according to political economist Dallas Smythe, Schramm filed regular surreptitious reports on Smythe's activities at the University of Illinois during the 1950s and 1960s. See Smythe, as cited in Babe (2000: 115). Among Schramm's publications was the co-authored book, The Reds Take A City (Rutgers University Press, 1951); material in his seminal, The Process and Effects of Mass Communication (1954), was prepared initially, according to Simpson "as training materials for U.S. government propagandas programs" (Simpson: 108).

11. Lerner, for example, was a towering figure behind the media as development paradigm; by allowing modern media and their consumerist messages into "developing countries," he alleged, modernization would occur rapidly through the demonstration effect and the desire to emulate the west (Lerner: 1958). These thoughts were taken up by, among others, Schramm, Rogers, and de Sola Pool. Even into the 1990s de Sola Pool was posthumously championing "free flow" for giving (international) audiences what they want (Pool 1990).

12. They write, for example: "Knowledge, more than ever is power. The one country that can best lead the information revolution will be more powerful than any other. For the foreseeable future, that country is the United States. America has apparent strength in military power and economic production. Yet its more subtle comparative advantage is its ability to collect, process, act upon, and disseminate information, an edge that will almost certainly grow over the next decade. This advantage stems from Cold war investments and America's open society, thanks to which it dominates important communications and information processing technologies--space-based surveillance, direct broadcasting, high-speed computers--and has an unparalleled ability to integrate complex information systems." (Nye and Owens: 20).

13. Other prominent members of the Yale School of deconstruction included Harold Bloom, Geoffrey Hartman and J. Hills Miller.

14. According to Lazarsfeld, "critical research ... seems to imply ideas of basic human values according to which all actual or desired effects should be appraised." (Lazarsfeld 1972: 160.

15. Earlier he defined the hyperreal as "the generation by models of a real without origin or reality" (p. 2).

\section{References}

Associated Press. 2006. "George Gerbner, Studied TV Culture." Washington Post, January 2, p. B4.

Babe, Robert E. 1995. Communication and the Transformation of Economics. Boulder: Westview Press.

-..-. 2000. Canadian Communication Thought: Ten Foundational Writers. Toronto:University of Toronto Press.

----. 2006. Culture of Ecology: Reconciling Economics and Environment. Toronto: University of Toronto Press.

Barlow, John Percy. 1996. "A Declaration of the Independence of Cyberspace." Available at: http://www.eff.org/ barlow/ Declaration-Final.html.

Barlow, Maude and Tony Clark. 1997. MAI, Toronto: Stoddart.

Barson, Michael. 1992. Better Dead Than Red. New York: Hyperion.

Beard, Charles A. and Mary Beard. 1930. The Rise of American Civilization. New York: Macmillan.

Beniger, James. 1986. The Control Revolution: Technological and Economic Origins of the Information Society. Cambridge: Harvard University Press.

Berger, Peter and Thomas Luckmann .1966. The Social Construction of Reality. Harmondsworth: Penguin.

Blum, D. Steven. 1984. Walter Lippmann: Cosmopolitanism in the Century of Total War. Ithaca: Cornell University Press.

Blumler, Jay and Dennis McQuail. 1968. Television in Politics: Its Uses and Influences. London: Faber and Faber.

Blumler, Jay and Elihu Katz, eds. 1974. The Uses of Mass Communication. Beverly Hills: Sage.

Boulding, Kenneth. 1956. The Image: Knowledge and Life in Society. Ann Arbor: University of Michigan Press.

-.--. 1987. Ecodynamics: A New Theory of Societal Evolution. Beverly Hills: Sage Publications.
Braman, Sandra. 1990. "Trade and Information Policy." Media, Culture and Society 12:361-385.

Brzezinski, Zbigniew. 1970. Between Two Ages: America's Role in the Technetronic Era. New York: Viking Press.

Baudrillard, Jean. 1983. Simulations. Translated by Paul Foss, Paul Patton and Philip Beitchman. New York: Semiotext[e].

----. 2001. Jean Baudrillard: Selected Writings. Ed. Mark Poster. Stanford: Stanford University Press.

Carey, James W. 1996. "The Chicago School of Communication Research.” In Eve Munson and Catherine Warren, eds. James Carey: A Critical Reader. Minneapolis: University of Minnesota Press: 14 - 33 .

Chaffee, Steven H. and John L. Hochheimer. 1985. "The Beginnings of Political Communication Research in the United States: Origins of the 'Limited Effects' Model." In Michael Gurevitch and Mark R. Levy, eds. Mass Communication Review Yearbook. Vol 5. Beverly Hills: Sage Publications.

Chandler, Daniel. 1994. "Why Do People Watch Television?" Available at: http://www.aber.ac.uk/media/Documents/short/ usegrat.html

Choike. 2005. "UNESCO Convention on Cultural Diversity." Available at: http://www.choike.org/nuevo_eng/ informes/2286.html

Cobley, Paul. 1996. "Interpretation, Ideation and the Reading Process." In Paul Cobley, ed. The Communication Theory Reader. London: Routledge: 405-6.

Compton, James. 2004. The Integrated News Spectacle: A Political Economy of Cultural Performance. New York: Peter Lang. 
Crozier, Michel, Samuel Huntington, and Oji Watanuki. 1975. The Crisis of Democracy. New York: New York University Press.

Czitrom, Daniel. 1982. Media and the American Mind: From Morse to McLuhan. Chapel Hill: University of North Carolina Press.

Delia, Jesse. 1987. "Communication Research: A History." In Charles R. Berger and Steven Chaffee, eds. Handbook of Communication Science. Newbury Park: SAGE Publications: 20-98.

Dewey, John. 1922. "Review of Public Opinion by Walter Lippmann.” New Republic 30: 286-88.

----. 1927. The Public and Its Problems. Chicago: Swallow Press.

Easthope, Anthony. 1991. Literary Into Cultural Studies. London: Routledge.

Ewan, Stuart. PR!: A Social History of Spin. New York: Basic Books.

Fish, Stanley. 1980. Is There a Text in this Class? The Authority of Interpretive Communities. Cambridge: Harvard University Press.

Grierson, John. 1979. “Learning From Television.” In Forsyth Hardy, ed. Grierson on Documentary. London: Faber and Faber: 210 - 219; first published in Contrast, summer, 1963.

Hall, Stuart. 1980. "Encoding/decoding." In S. Hall, D. Hobson, A. Lowe, and P. Willis, eds. Culture, Media, Language. London: Hutchinson: 128-138.

Hardt, Hanno. 1992. Critical Communication Studies: Communication, History \& Theory in America. London: Routledge: 42 - 76.

Hayles, N. Katherine. 1999. How We Became Posthuman: Virtual Bodies in Cybernetics, Literature, and Infomatics. Chicago: University of Chicage Press.

Herman, Edward S. and Noam Chomsky. 1988. Manufacturing Consent: The Political Economy of Media. New York: Pantheon.

Innis , Harold A. 1951. The Bias of Communication. Toronto: University of Toronto Press.

-.--. 1952. Empire and Communications. Toronto: University of Toronto Press.

Jameson, Frederic. 1991. Postmodernism: Or, the Cultural Logic of Late Capitalism. Durham: Duke University Press.

Katz, Elihu and Paul F. Lazarsfeld. 1955. Personal Influence: The Part Played By People in the Flow of Mass Communication. New York: Free Press.

Katz, Elihu and Michael Gurevitch. 1974. "Uses of Mass Communication By the Individual.” In W. P. Davidson and F. Yu, eds. Mass Communication Research: Major Issues and Future Directions, eds. New York: Praeger.

Klapper, Joseph. 1960. The Effects of Mass Communication. New York: Free Press.

Lazarsfeld, Paul Felix. 1941. "Remarks on Administrative and Critical Research." In Studies in Philosophy and Social Sciences 9(1). Reprint: Lazarsfeld. 1972. "Administrative and Critical Research.” In Qualitative Analysis: Historical and Critical Essays. Boston: Allyn and Bacon Inc.: 157-167.

Lazarsfeld, Paul F., Bernard Berelson and Hazel Gaudet. 1944. The People's Choice. New York: Duell, Sloan and Pearce.

Lears, T.J. Jackson. 1983. "From Salvation to Self-Realization: Advertising and the Therapeutic Roots of the Consumer Culture 1880-1930." In Richard Wightman Fox and T.J. Jackson Lears, eds. The Culture of Consumption. New York: Pantheon.

Lee, Richard E. 2003. Life and Times of Cultural Studies: The Politics and Transformation of the Structures of Knowledge. Durham: Duke University Press.
Lent, John. 1995. A Different Road Taken: Profiles in Critical Communication. Boulder: Westview Press.

Lerner, Daniel. 1958. The Passing of Traditional Society: Modernizing the Middle East. Glencoe, Illinois: The Free Press. Lippmann, Walter. 1965. Public Opinion. New York: The Free Press. First published 1922.

Littlejohn, Stephen. 1992. Theories of Human Communication, 4th ed. Belmont: Wadsworth.

Lowery, Shearon and Melvin DeFleur. 1988. Milestones in Mass Communication Research, 2d ed. New York: Longman.

Macpherson, C.B. 1978. Property: Mainstream and Critical Positions. Toronto: University of Toronto Press.

Mattelart, Armand. 1994. Mapping World Communication: War, Progress, Culture. Translated by Susan Emanuel and James A. Cohen. Minneapolis: University of Minnesota Press.

Mattelart, Armand and Michèle Mattelart. 1995. Theories of Communication. London: Sage.

Morgan, Michael, ed. 2002. Against the Mainstream: The Selected Works of George Gerbner. New York: Peter Lang.

Nordenstreng, Kaarle and Herbert I. Schiller, eds. 1979. National Sovereignty and International Communication: A Reader. Norwood, N.J.: Ablex Publishing Corporation.

Nye, Joseph S. and William A. Owens. 1996. "America's Information Edge." Foreign Affairs. March/April: 20-36.

O’Donnell, Kevin. 2003. Postmodernism. Oxford: Lion Publishing.

Pool, Ithiel de Sola. 1966. "Communication and Development." In M. Weiner, ed. Modernization: The Dynamics of Growth. Washington, D.C.: Voice of America, 1966: 106 - 110.

..--. 1983. Technologies of Freedom. Cambridge: Harvard University Press.

-..-. 1990. Technologies Without Boundaries. Cambridge: Harvard University Press.

Poster, Mark. 1990. The Mode of Information: Poststructuralism and Social Context. Chicago: University of Chicago Press.

-.--. 1994. "The Mode of Information and Postmodernity." In David Crowley and David Mitchell, eds. Communication Theory Today. Stanford: Stanford University Press.

----. 2001. "Introduction." Jean Baudrillard: Selected Writings. ed. Mark Poster, Stanford: Stanford University Press.

Preston, William, Edward S. Herman, and Herbert I. Schiller. 1989. Hope and Folly: The United States and UNESCO 1945 - 1985. University of Minnesota Press.

Roberts, Paul William. 2005. “The Flagging Empire.” The Globe and Mail. 10 September 2005: F1 - F5.

Rogers, Everett and Floyd Shoemaker. 1971. Communication of Innovations: A Cross Cultural Approach. New York: Free Press.

Rogers, Everett. 1994. A History of Communication Study: A Biographical Approach. New York: Free Press.

Sardar, Ziauddin and Borin Van Loon. 1999. Introducing Cultural Studies. Cambridge, UK: Icon Books.

Schramm, Wilbur. 1954. "Foreword." The Process and Effects of Mass Communication. Urbana: University of Illinois Press.

----. 1971. "The Nature of Communication between Humans." In Wilbur Schramm and Donald F. Roberts, eds. The Process and Effects of Mass Communication, revised ed. Urbana: University of Illinois Press.

----. 1997. The Beginnings of Communication Study in America: A Personal Memoir. Thousand Oaks: Sage.

Schwartz, Richard A. 1998. Cold War Culture: Media and the Arts, 1945-1990. New York: Checkmark Books.

Shanahan, James and Michael Morgan. 1999. Television and Its Viewers: Cultivation Theory and Research. Cambridge: Cambridge University Press. 
Shannon, Claude E. and Warren Weaver. 1949. The Mathematical Theory of Communication. Urbana, Illinois: University of Illinois Press.

Simpson, Christopher. 1994. Science of Coercion: Communication Research \& Psychological Warfare 19451960. Oxford: Oxford University Press.

Smythe, Dallas W. 1957. The Structure and Policy of Electronic Communication. Urbana: University of Illinois.

----.. 1985. "One Canadian Perspective: Clear Across Australia." Prometheus 3 (2): 431-53.

Sussman, Gerald and John Lent. 1991. "Introduction: Critical Perspectives on Communication and Third World Development." In Gerald Sussman and John A. Lent, eds. Transnational Communications: Wiring the Third World. Newbury Park: Sage.

Turner, Graeme. 1990. British Cultural Studies: An Introduction. Boston: Unwin Hyman.
UNESCO. 1980. Many Voices, One World. (McBride Commission Report). Paris: UNESCO.

Webster, Frank. 1995. Theories of the Information Society. London: Routledge.

Wiener, Norbert. 1950. The Human Use of Human Beings: Cybernetics and Society. Republished, New York: Avon Books, New York, 1967.

Williams, Brian A. 1998. Thought and Action: John Dewey at the University of Michigan. Ann Arbor: Bentley Historical Library, University of Michigan. On-line version accessed March 302006 at: http://www.soe.umich.edu/dewey/ thoughtnews/index.html

Wimmer, Roger D. and Joseph R. Dominick. 2005. Mass Media Research, 8th ed. Belmont: Wadsworth.

Zinn, Howard. 2005. A People's History of the United States. Revised. New York: Harper Perennial. 
